\begin{tabular}{l|c|c}
\hline ISSN: 0001-5113 & ACTA ADRIAT., & ORIGINAL SCIENTIFIC PAPER \\
AADRAY & $61(1): 13-26,2020$ & \\
\hline
\end{tabular}

\title{
Oil seeps detection and mapping by SAR imagery in the Adriatic Sea
}

\author{
Andrei Yu. IVANOV ${ }^{1}$ and Mira MOROVIĆ 2 \\ ${ }^{1}$ Shirshov Institute of Oceanology, Russian Academy of Sciences, Moscow, Russia \\ ${ }^{2}$ Institute of Oceanography and Fisheries, Split, Croatia \\ Corresponding author, e-mail:ivanoff@ocean.ru
}

\begin{abstract}
This study provides a new perspective on the hydrocarbon seeps in the Adriatic Sea, supporting both the environmental issues and eventual oil and gas exploration. Remote sensing techniques, particularly synthetic aperture radar (SAR) images are used to detect oil slicks on the sea surface. In such a way two groups of oil slicks have been detected in the Northern and Central Adriatic Sea on the SAR images acquired by the European Sentinel-1A and Sentinel-1B satellites in 2017-2018. Analysis of SAR images together with bathymetry, geological and geophysical data in geographic information system (GIS) have shown that these oil slicks, visible on the sea surface have natural origin, i.e. are seepage phenomena, associated to existing marine hydrocarbon systems. These oil slicks were concentrated over the shallow shelf, and repeatedly or episodically occur in the areas of interest, and are related to local oil-and-gas bearing sediments. Findings of the seeps and seep candidates that passed unnoticed from public attention indicate the effectiveness of the approach used. Finally, it is concluded that the frequent SAR imagery is an excellent tool for monitoring of seepage phenomena, and the results indicate that the use of remote sensing methods can be considered as a good approach to support oil and gas exploration in the Adriatic Basin.
\end{abstract}

Key words: Adriatic Sea, SAR images, oil slicks, oil seepage, cold seeps, GIS approach

\section{INTRODUCTION}

Encyclopedia sources usually characterize natural seepage as a flow of gaseous or liquid hydrocarbons that emerges from sources in the sedimentary basins of the Earth. Traditionally the «term «seepage» in geology is restricted to the hydrocarbon gas flow, such as alkanes methane, ethane, etc., with minor components of $\mathrm{CO}_{2}, \mathrm{~N}_{2}, \mathrm{H}_{2} \mathrm{~S}$ and other gases. The gas seep is a seep releasing only gaseous hydrocarbons, whereas oil seep mainly releases liquid hydro- carbons. Usually the seeps are formed in a rich petroleum oil-and-gas sediment through microbial or thermal conversions of organic matter in source rocks, generally shales or limestones. This flow of gaseous and liquid hydrocarbons from bottom seeps can be steady or episodic, slow or rapid, visible or invisible. Sources on the sea bottom are considered to be pockmarks, cold seeps and mud volcanoes. The amount of released gas and oil by seeps varies largely. While emitted gas to the water column is coming to the sea surface and further to the atmosphere, 
the oil remains on the sea surface and appear as slicks (MACDONALD et al., 2002). It is generally accepted that the release of oil from the interior is mostly triggered by tectonic and seismic processes.»

It has been discovered that this phenomenon is widespread in many marine basins with appropriate sediments in the basement. By conventional geophysical and geological methods, natural seepage of hydrocarbons has been discovered in most of the world's petroleum basins (KVENVOLDEN \& COOPER, 2003). Active hydrocarbon seeps have been recorded in the Gulf of Mexico, the Caspian Sea, the Black Sea, and in many other places of the ocean (JUDD \& HOVLAND, 2007). According to KVENVOLDEN \& COOPER (2003) the natural seeps make almost a half of all crude oil entering into the marine environment.

Satellite remote sensing, in particular synthetic aperture radar (SAR), is an effective tool to detect and analyze oil seeps via oil slicks floating on the sea surface. Oil films suppress short surface waves, reduce backscattering to the SAR antenna and form pronounced dark signatures on SAR images (BREKKE \& SOLBERG, 2005; IVANOV, 2011). For the first time, the slicks related to oil seepage have been detected on the SAR images acquired during the Seasat mission in offshore Southern California in 1978. Since the launch of the other SAR-equipped satellites, many oil slicks associated to cold seeps have been detected on the SAR images of the ERS$1 / 2$, Envisat, Radarsat- $1 / 2$ and other satellites (WILLIAMS \& LAWRENCE, 2002; DE MIRANDA et al., 2004; ZATYAGALOVA et al., 2007; EVTUSHENKO \& IVANOV, 2013; MACDONALD et al., 2015). Until now SAR images are routinely used to detect natural hydrocarbon seepage at the sea surface (EVTUSHENKO \& IVANOV, 2013; MACDONALD et al., 2015; JATIAULT et al., 2017; NAJOUI et al., 2018; BAYRAMOV et al., 2018).

Croatia has several active underground oil fields on the land but also considerable amount of gas has been found in the Croatian seabed, particularly in the Northern Adriatic. In such fields, oil often coexists with gas, although sometimes the oil reserves might not be large enough to allow exploitation. The investigations started in the 70s last century and experimental drilling took place in the $80 \mathrm{~s}$. Commercial exploitation of gas started in the late 90s, after the agreement between INA (Croatian) and ENI (former AGIP, Italian) oil companies. Production in the Northern Adriatic started on the Ivana and Marica gas fields in the late 80s and in Ida and Ika fields in 2006. Exploitation platforms are interconnected with underwater gas pipelines and with the land. The production delivers $4.3 \cdot 10^{6} \mathrm{~m}^{3} /$ day (MALVIĆ \& VELIĆ, 2008). These reserves, which are estimated as $20 \cdot 10^{12} \mathrm{~m}^{3}$, are about to be exhausted in a near future.

Since the Adriatic Sea is relatively well investigated with the common standard geological-geophysical methods, only new advanced techniques could help in finding new oil seeps related to oil/gas reserves and systematic investigation with non-invasive SAR techniques may be of great help. Remote sensing researchers have developed the tools and methods to detect oil pollution of the Adriatic Sea, to estimate its distributions and extent, and even the tools to identify oil spill sources and actual polluters (PERKOVIĆ et al., 2016; MOROVIĆ et al., 2015; 2016). Other projects are devoted to joint studies correlating natural oil slicks detected in SAR imagery with 2D seismic data, see, e.g., SPECTRUM GEO (2017). Moreover, satellite remote sensing readily detects oil floating on the sea surface over active hydrocarbon seeps, providing means to survey seeps, determine their locations across the oilcontaining regions and finally can estimate the seep rates. In this paper we present, analyze and discuss two cases of detecting oil seeps in the Adriatic Sea using SAR images.

\section{Oceanographic settings}

The Adriatic Sea is a small marginal sea in the north part of the Mediterranean (Fig. 1a). Its depth varies from very shallow in the northern most part (average $30 \mathrm{~m}$ ). Further southern, Central Adriatic reaches $300 \mathrm{~m}$ in the Jabuka Pit, about 100-180 m at Palagruža Sill, and reaches depth of $1276 \mathrm{~m}$ in the Southern Adriatic pit.

General circulation in the Adriatic is cyclonic, alternating between winter and summer regimes 

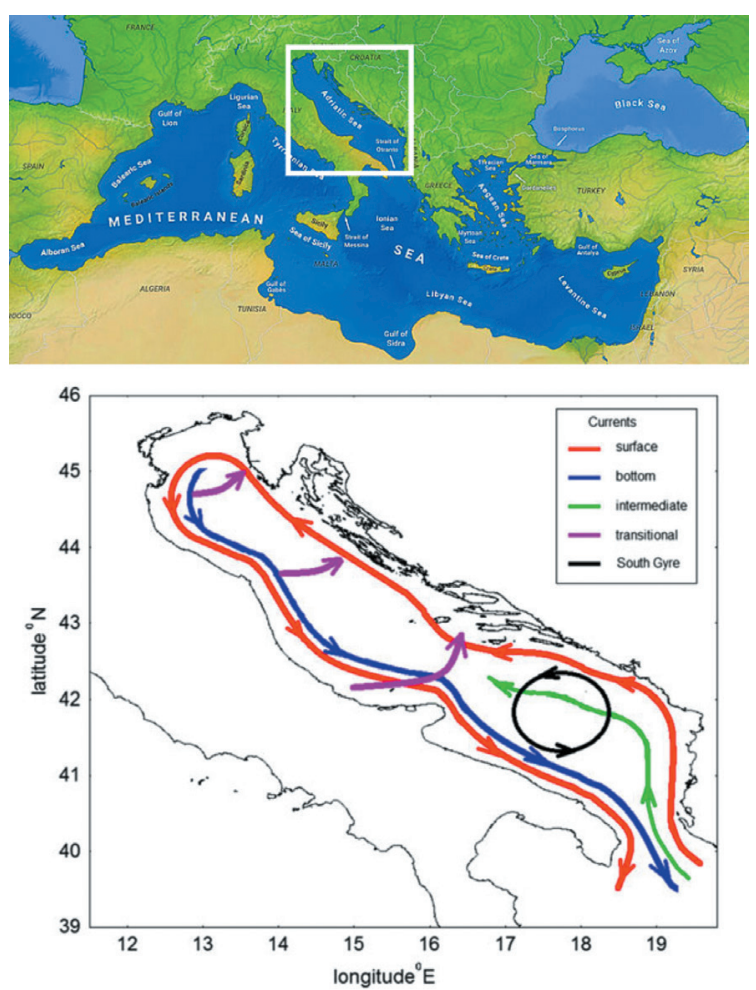

Fig. 1. a) The Mediterranean and the Adriatic Sea in white rectangle, and b) Currents in the Adriatic Sea (from MOROVIĆ et al., 2016).

(ZORE-ARMANDA, 1956; ARTEGIANNI, 1996; ARTEGIANNI et al., 1997) and varying from annual to decadal scale due to stronger or weaker intrusion of the Mediterranean waters (BULJAN, 1953; GRBEC et al., 2009).

However, strong synoptic disturbances at time scales from days to weeks could locally produce currents of different directions. These would be provoked by the sequence of typical winds Sirocco and Bora in the Region off Rovinj. Typical summer wind in the region is Maestral.

General circulation would cause NW currents along the East coast of the Northern Adriatic, which would be enhanced by Sirocco wind. Strong Bora wind would force the currents towards the West coast allowing local compensation currents in the opposite direction, influenced by topography of the East coast (Fig 1b). Strong Bora episodes often provoke a doublegyre response in the Northern Adriatic north of the Po Delta - Pula line (KUZMIĆ et al., 2007). On the Italian side off Civitanova, the SW branch of general circulation would also be influenced by the same winds (Sirocco and Bora).

It is clear that spreading of oil slicks can be influenced by a number of factors like seasons, thermohaline conditions, winds, currents, tides, free and inertial oscillations as well as physicalgeography features. For dispersion of slicks crucial are processes at rather short time scales from hourly to diurnal, particularly the wind stress.

\section{Area of interest}

In the Adriatic Sea the two regions of interest (ROI) have attracted our attention: first located near the Italian shoreline off the town Civitanova Marche in the Central Adriatic Sea, and the second one in the Northern Adriatic Sea off the Croatian town Pula (Fig. 2). According to the oceanographic and geological investigations, it is suggested that the sea there is influenced by sub-oceanic processes. The presence of gas and oil leaking in the sea was reported in many studies (JUDD \& HOVLAND, 2007). A number of them have been studied by in situ measurements (see, for example, ETIOPE et al., 2014), however, recent attempts have been made to detect and study seepage using remote sensing imagery (MOROVIĆ et al., 2016).

\section{Geological-geophysical settings}

To verify seep findings all available information about the marine basin has been collected and supplementary used to support SAR image analysis. Geological and geophysical characteristics of the Adriatic Sea are here briefly presented to demonstrate the potential of the region as a bearing ground of hydrocarbons.

The Adriatic micro-plate is a part of the African plate that collides with the Eurasian plate since Early Cenozoic. It is subducting under the Eurasian plate in the N/NE direction with a rate of $4 \mathrm{~mm} /$ year (OLUIĆ, 2015). Crystalline rocks of the Adriatic micro-plate reach 6 to $14 \mathrm{~km}$ depth (BRDAREVIĆ \& OLUIĆ, 1979) over which the sedimentary rocks appeared in submerged basin depressions, composed mainly of biogenic carbonates and evaporites. 


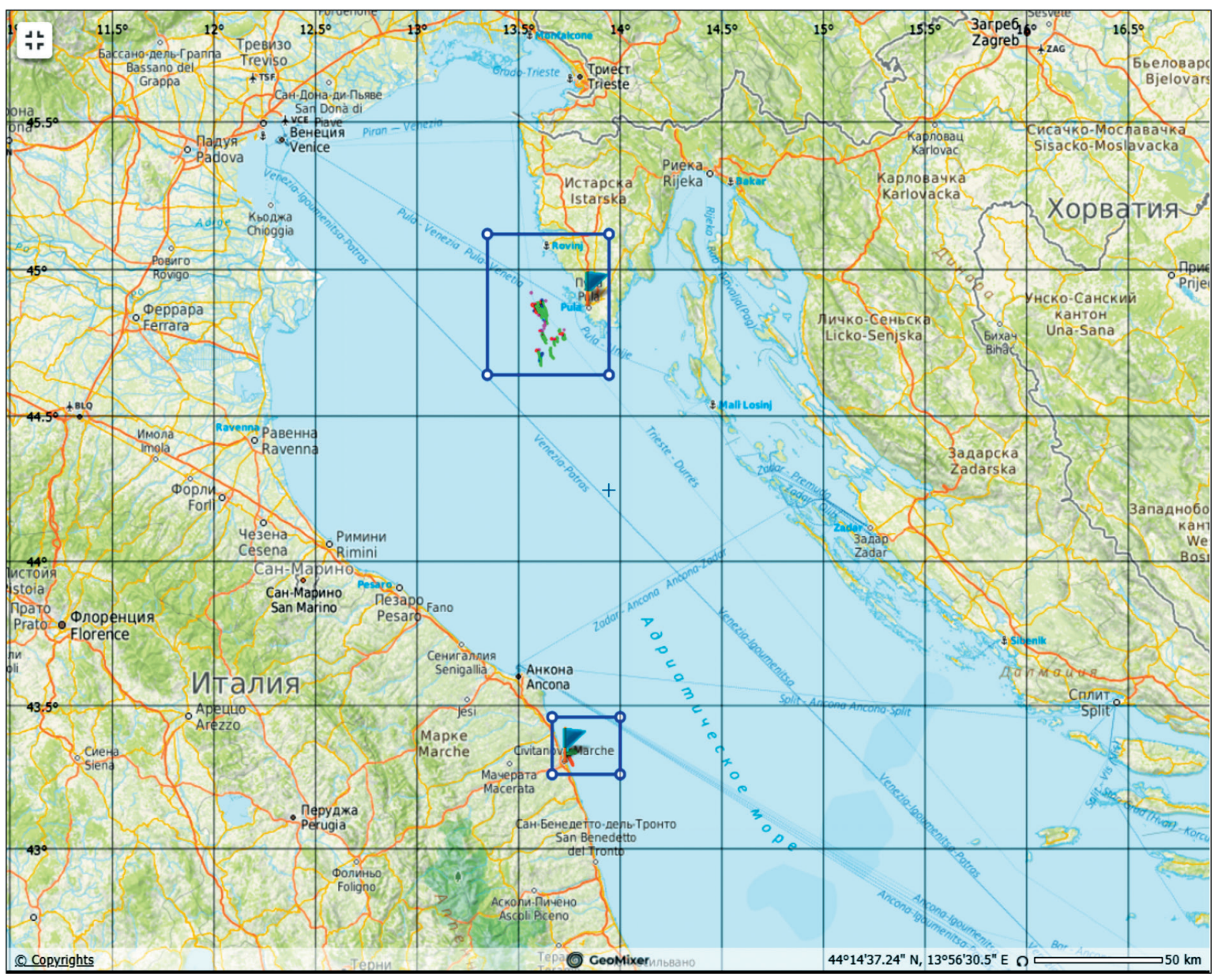

Fig. 2. Regions of interest in the Adriatic Sea shown by blue squares; flags show the towns of Civitanova Marche and Pula.

In the most important depression the Central Adriatic Depression (BRDAREVIĆ \& OLUIĆ, 1979) there are several different seafloor morphologies like pockmarks, mud volcanoes and mud carbonate mounds. These structures enable gas to penetrate trough fractures and create pathways for fluid seepage, caused by holokinetic activity (GELETTI et al., 2008). A number of active faults have been detected (OLUIĆ, 2015), forming different structures due to complex tectonics, magmatism, gravity, and salt tectonics (TUFEKČĆĆ, 2015). The sediment diapirs are linked to continuous gas release (HOVLAND \& CURZI, 1989) and salt structures (traps) collecting and releasing gas through the seeps.

The Adriatic basin contains biogenic and deep thermogenic petroleum systems. The oil deposits were found by seismic research (MAT-
TAVELLI et al., 1991) in carbonate reservoirs at depths of $4000-5300 \mathrm{~m}$, with the main reservoir found at $1300 \mathrm{~m}$ (CASERO \& BIGI, 2013).

Many shallow deposits of gas are located there in water depths of 20-100 m. Between the 60 s and 80 s last century about 200 oil and gas fields have been discovered in the Adriatic Sea, mostly in the Italian sector, together with several tens in the Croatian sector (COTA et al., 2015). Gas and oil emissions are often triggered by earthquakes, caused by tectonic faulting (JUDD \& HOVLAND, 2007). It has been also noted that pockmarks are particularly active before and during the earthquakes (DANDO et al., 1995) and gas is usually emitted immediately prior to the earthquakes (HOVLAND et al., 2002). The gas evaporates while the oil remains on the sea surface and can be detected as dark patches on SAR 
images (ETIOPE et al., 2014) pointing to petroleum reserves under the seabed. So far, one seep site located off the Italian town Civitanova Marche has been discovered by conventional methods (ETIOPE et al., 2014).

The seismicity of the Adriatic Sea is pronounced, and is potentially higher at the Italian side near Civitanova than close to Pula in the Northeast Adriatic Sea.

\section{MATERIALS AND METHODS}

Remote sensing with SAR is playing increasingly important role in detection of different kind of oil slicks (BREKKE \& SOLBERG, 2005). It is well-known that modern SAR instruments onboard such satellites as Radarsat-2, TerraSAR$\mathrm{X}$, Cosmo-SkyMEDs, and recent Sentinel-1A and Sentinel-1B, provide very good spatial coverage of marine basins for oil slick monitoring with adequate spatial and temporal resolution. Oil escaping from a seep can create repeated oil slicks on the sea surface above its location on the seabed. Oil seep slicks are seen in SAR images as dark patches with shapes, which are rather distinct and often linear or curved. The geometric features of seep slicks are the result of short-term local changes in wind and currents. Their reproducing in time and in the same place, i.e. repeatability and grouping in space, are their most discriminating characteristics. This is why the oil seep/slicks have distinctive shapes that can help to distinguish natural oil seeps from oil pollution or other similar phenomena (IVANOV, 2011; NAJOUI et al., 2018).

In this study SAR images were used to detect oil seeps from space. Through mapping, spatial and temporal characteristics of oil slicks can be analyzed. For this reason, more than 50 Sentinel-1A and Sentinel-1B SAR images, acquired in the Interferometric Wide Swath mode (250 x $250 \mathrm{~km}$ swath, 5 x $20 \mathrm{~m}$ resolution) in the period 2017-2018 were selected and analyzed. They provide frequent coverage of the ROIs in the Northern and Central Adriatic Sea (Fig. 2).

The ability of SAR to detect natural oil slicks strongly depends on wind speed and sea-state (IVANOV, 2011). In low wind conditions look- alikes are formed and detection of seep slicks is challenged, while in high wind conditions oil films tend to disappear from the sea surface due to breaking-up. The most favorable wind speed range for oil seep slick detection is established to be $2-3-6-7 \mathrm{~m} / \mathrm{s}$ (IVANOV, 2011). That is why all SAR images were collected under appropriate wind and sea-state conditions, at wind speed not exceeding $6-7 \mathrm{~m} / \mathrm{s}$.

Each SAR image may show a number of oil slicks, while only some consist of an amount of oil, which came to the sea surface from a bottom source and is propagated at the surface under the action of surface currents and wind. With purpose to detect and identify slicks a semiautomatic technique has been used. Dark targets in SAR images were detected automatically by a computer processing method. Subsequently, seepage slicks are distinguished from other detected dark patches, or so-called look-alikes, by trained analysts. After preprocessing of SAR images, the image segmentation is needed to extract oil seep contours and shapes. In particular, processing and analysis of SAR images included the following: (1) automatic image pre-processing, (2) semi-automatic detection of dark features, (3) interactive identification on the basis of geometrical and textural properties and contextual information under supervision of trained experts familiar with the methodology described by WILLIAMS \& LAWRENCE (2002), and (4) discrimination among other possible look-alikes. For each oil slick - a seep candidate, geometric features (describing the length, area and shape) and radiometric features (describing backscatter information and contrast) were also taken into account. Then all identified seep slicks were segmented, vectorized and georectified to the map projection.

Finally, these vector layers were integrated according to a geo-information (GIS) approach (IVANOV \& ZATYAGALOVA, 2008) using the GeoMixer web-GIS application (http://geomixer.ru). In summary, after preliminary image screening, employed was standard image processing and the semi-automatic routine to delineate contours, the dark patches on SAR images. Finally, the web-GIS Geomixer was used to collect all 
outlines in one map, where the geospatial tools allowed extracting several oil slicks characteristics, such as lengths, shapes, area and other useful information.

Available ancillary information was also used for more comprehensive analysis. This comprised wind speed and direction provided by weather station at the Pula airport before and close to the satellite image acquisition time, coastline features, bathymetry, oil and gas installations and other useful information from the nautical charts provided by C-MAP, and available through SCANEX geoportal and Adriatic Atlas (https://atlas.shape-ipaproject.eu).

\section{Oil slicks and seep manifestations on SAR images}

Seepage detection by SARs is a proven remote sensing method for mapping surface oil seep manifestations, which could provide the first indication of petroleum systems in different marine basin. The surface manifestations of natural oil seepage can be detected and identified on the basis of visibility in satellite images, spatial dimension, shape and other characteristics.

Spatial analysis of the SAR images in GIS on different images taken at different dates has discovered active underwater seeps, often form clusters of slicks or seep slicks. On the other hand, the slick clusters can be the results of action of group of similar sources or sub-seeps, because seepage vents are seldom singular. Undoubtedly clusters of slicks above the local structures (Fig. 3) can mark locations of the underwater oil and gas sources (DE MIRANDA et al., 2004; ZATYAGALOVA et al., 2007).

The position of an oil source at the bottom can be determined by analyzing the grouping pattern of oil slicks detected on the SAR images acquired in different times. In this why it is possible to establish approximate coordinates of the bottom sources of seeps.

\section{RESULTS AND DISCUSSION}

The two groups of oil seeps analyzed are located in the central and northern sections of the Adriatic Sea, from which crude oil can enter the marine environment. Routinely acquired Sentinel-1A and Sentinel-1B SAR images of the European Space Agency satellites in 2017 2018, clearly showed seep oil slicks in these regions. Processing of the collected SAR images with detected slicks in combination with the GIS approach has revealed a link of these slicks with the possible bottom sources on the local sedimentary structure in the Adriatic Sea. This analysis provides both new insight into this phenomenon and new information to help understanding the nature of these oil seeps. Based on the analysis of collected SAR images and other supplementary geospatial data, the information on the source positions on the bottom and estimates of oil volumes entering the sea surface are obtained. In the next sections main results are presented and discussed.

\section{Seeps off Civitanova Marche (Italy)}

This seep is located in the Central Adriatic Sea (Lat $43^{\circ} 20^{\prime} 02^{\prime \prime} \mathrm{N}$; Lon $\left.13^{\circ} 44^{\prime} 19^{\prime \prime} \mathrm{E}\right), 2$ $\mathrm{km}$ off the coast of Fontespina village, $2.4 \mathrm{~km}$ NNE of Civitanova Marche, and 4 km NW from the Sarago Mare 1 oil production platform (Fig. 3). At the figure (photo from ETIOPE et al., 2014), small gas bubbles $(1-2 \mathrm{~cm})$ and oil iridizing at the sea surface can be seen. It is known that the seep in this location was observed by port authorities and fishermen already in the early $20^{\text {th }}$ century and it looks like was first reported by Reeves in 1953. This area was investigated for hydrocarbon in 1969 and 1985 and it was found that the source of it lays at a depth of $11 \mathrm{~m}$, covering the area of about $10 \mathrm{~km}^{2}$ and comprises several irregular spots of oil and gas trapped in the sediments below the mud, confirming the source of the slicks as a natural seepage phenomenon (ETIOPE et al., 2014).

Collected SAR images show very frequent appearance of oil slicks on the sea surface at favorable wind conditions (Fig. 4a). Using the GIS method, the spatial distribution pattern of seep slicks off Civitanova was revealed (Fig. 4b). Searching the Sentinel-1A and Sentinel-1B archive of SAR images from 2017 and 2018, it was possible to find many images of natural 

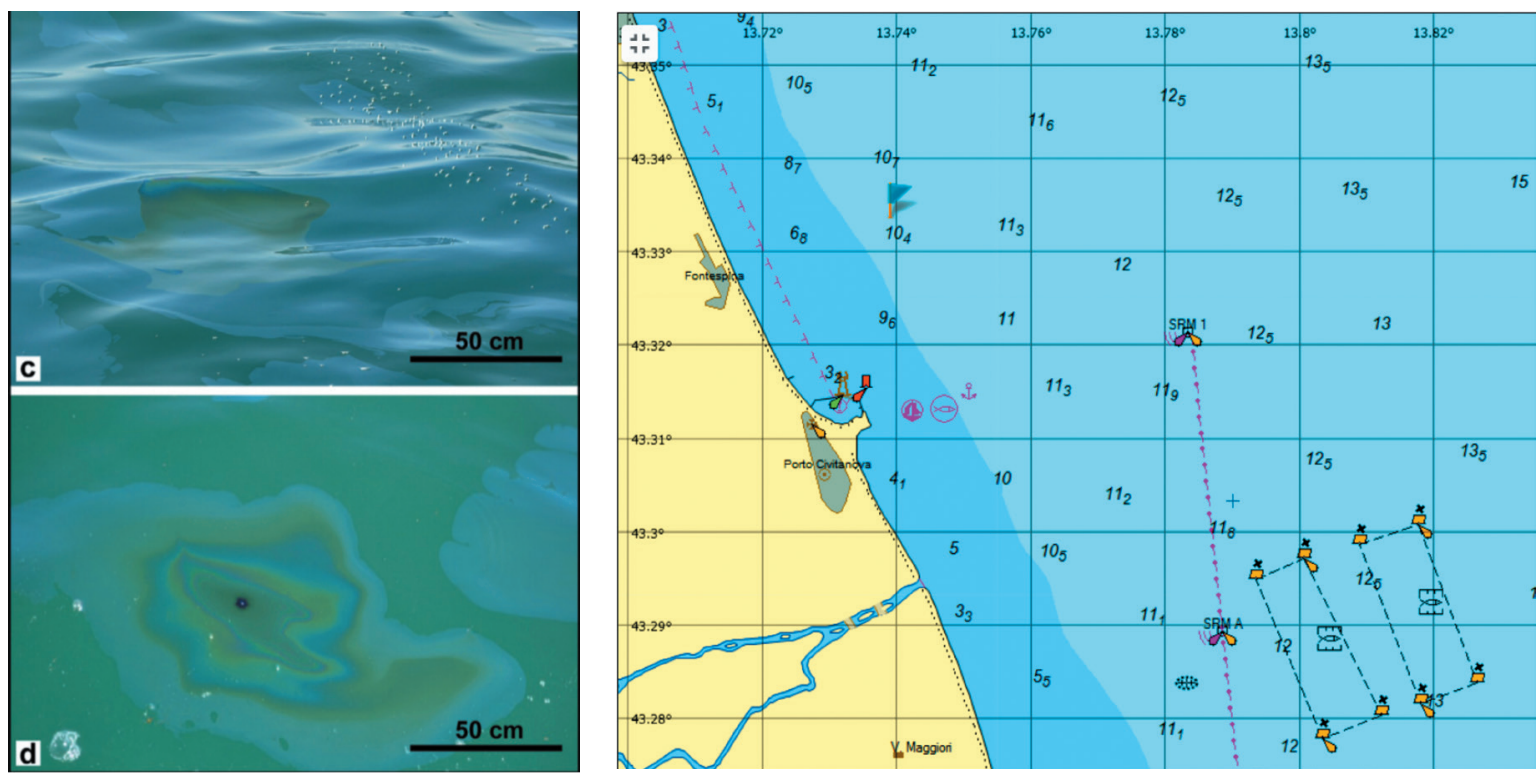

d 18

$50 \mathrm{~cm}$

Fig. 3. Seep manifestations off Civitanova Marche on the photos (from Etiope et al., 2014) taken from a ship with gas bubbles and oil slicks (film color is from rainbow to silver-gray - sheen) on the sea surface, and its position (flag) on the bathymetric map (right)

oil slicks - hydrocarbon seeps off Civitanova Marche. The figure shows maps of several examples of seepage slicks from the SAR image subscenes. Each oil slick represents a snapshot of certain amount of oil that reached the sea surface and moves from its origin under the action of prevailing coastal currents and wind. It is clear that in every snapshot, there is only one oil slick that came exactly from the seep. Moreover, on some SAR images a group of four slicks coming from different vents can be clearly seen.

In the figure $4 \mathrm{~b}$ the locations of oil seeps from selected 20 SAR images from the same period were integrated in one map, and locations of potential hydrocarbon reservoirs are depicted. It is visible that a lot of these slicks were spread under the influence of alongshore coastal currents in NW-SE direction. Also, some slicks deviated from this direction, going offshore under the action of the southern to southeastern winds. On the map (Fig. 4b) the distributions of the slicks (ten of twenty detected) and sizes are visible, and red square shows the most possible origin of underwater source. Slick length varied from 1.5 to $4.2 \mathrm{~km}$, while total area of individual slick did vary from $0.07 \mathrm{~km}^{2}$ to $3.8 \mathrm{~km}^{2}$.

Considering the slick areas measured from SAR images acquired at wind speeds between 2-6 $\mathrm{m} / \mathrm{s}$, the volumes of oil floating on the sea surface over this seep can be estimated. Considering medium to high flux of liquid hydrocarbons, minimum and maximum areas of oil slicks floating on the sea surface, i.e. $0.07 \mathrm{~km}^{2}$ and 3.8 $\mathrm{km}^{2}$ respectively, as well as mean oil content of about $0.3 \mathrm{t} / \mathrm{km}^{2}$ in rainbow-sheen colored films (oil film thickness is about $0.3 \mathrm{~mm}$ according to BAOAC (2016)), the estimates of emitted oil can be obtained. So, minimum volume estimate is $0.2 \mathrm{t}$ and maximum estimate is $1.1 \mathrm{t}$. Finally, analysis of the set of SAR images acquired in 2017-2018 showed that flow of liquid hydrocarbons from this seep is active, steady and repeating.

As suggested, there may be a link between seepage, deep fracture systems and geological features of the sea that is shown in recent studies by GELETTI et al. (2008), ETIOPE et al. (2014) and others. It is considered that oil leakage come from pockmarks on the seabed, and the documented seep activity testifies the compressive stress field in the area, most probably representing the mechanism of the hydrocarbon infiltration to the seafloor and further to the sea surface (GELETTI et al., 2008). Frequent regional seismic activity could be one of triggering mechanisms, since many recent epicenters of earthquakes were located in the Central Adriatic, particularly at the Italian side. 


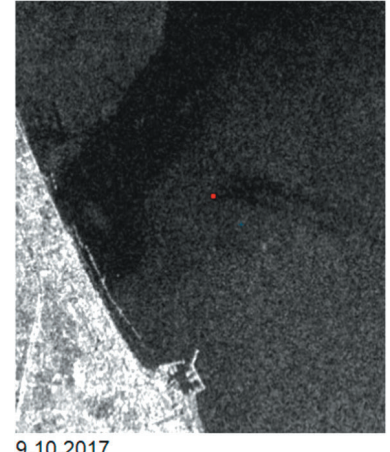

9.10 .2017

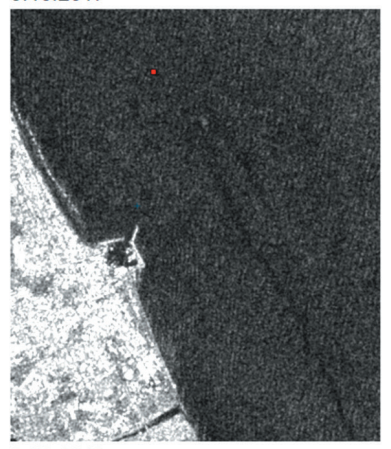

2.03.2018

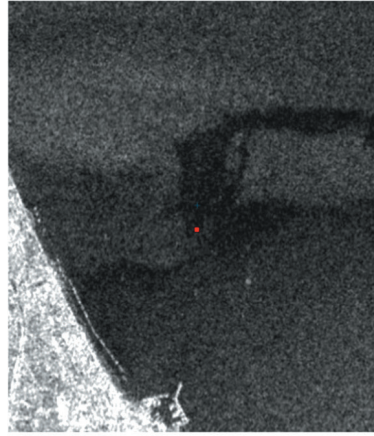

15.10.2017

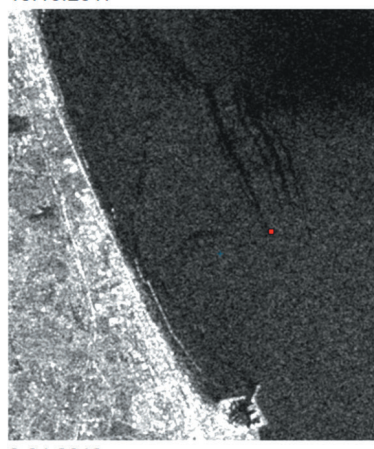

8.04 .2018

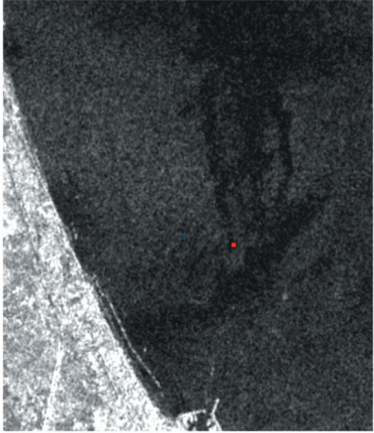

27.10.2017

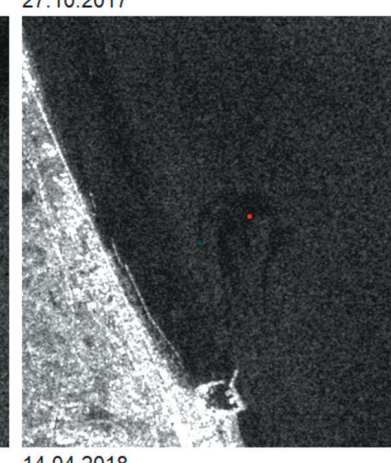

14.04 .2018

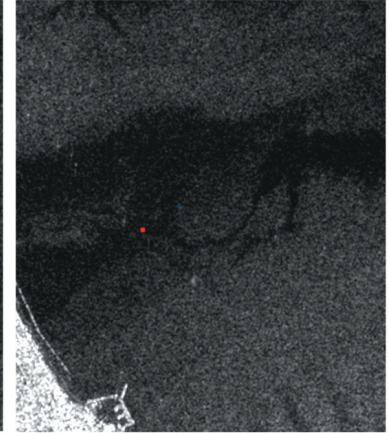

25.01.2018

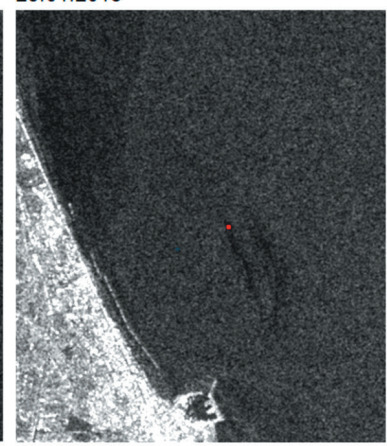

20.04.2018

Fig. 4a. Oil slicks (dark linear features) repeatedly detected on the Sentinel-1A/1B SAR images in 2017-2018 over the cold seep off Civitanova Marche (Italy; location of main seep is shown by small red square). Image (C) ESA

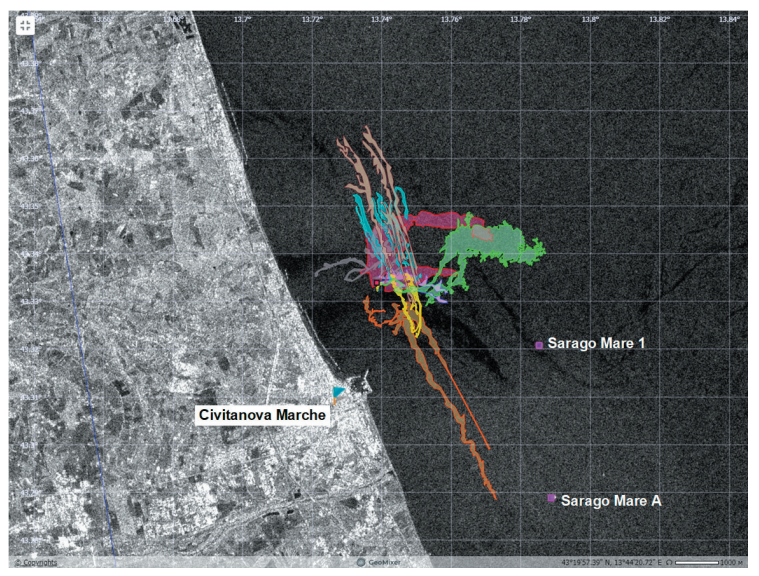

Fig. 4b. Oil slicks (color outlines) repeatedly detected on the Sentinel-1A/1B SAR images acquired in period October 2017 - October 2018 over the cold seep(s) off Civitanova Marche (main origin of slicks on the sea surface is shown by red square). Pink squares are oil production platforms. Image (C) ESA

\section{Seeps off Pula (Croatia)}

According to CONTI et al. (2002), the first report of gas seeping in the Northern Adriatic Sea was in 1940, when researcher Morgante described appearance of gas bubbles on the sea surface off Rovinj. A number of attempts to discover seeps here were recently made (see PERKOVIĆ et al., 2016). Anyway, oil slicks in this region were repeatedly imaged as compact or elongated dark patches on four SAR images only in 2018, acquired on $9^{\text {th }}, 10^{\text {th }}, 11^{\text {th }}$ and $15^{\text {th }}$ September. Fig. 5a shows two SAR images acquired on $11^{\text {th }}$ and $15^{\text {th }}$ September with oil seep slicks marked by flags.

On the SAR image acquired $11^{\text {th }}$ September (Fig. 5a, up) many slicks were detected. The typical seasonal condition in September (late summer) is characterized by the north-westerly wind, named Maestral. Such a wind rises typically in the early afternoon hours. The wind at the sea would blow offshore spatially uniform causing spreading of the oil slicks southwestward. On $11^{\text {th }}$ September in nearby Pula-airport station, around image acquisition time, west wind was blowing with speed of about $4 \mathrm{~m} / \mathrm{s}$ (Table 1). As seen from the image, the wind has caused spreading of all seep slicks in SW direction. On $15^{\text {th }}$ September, (Fig 5a, bottom) weak eastern wind was blowing and fresh slicks did not show particular direction of spreading, i.e. 

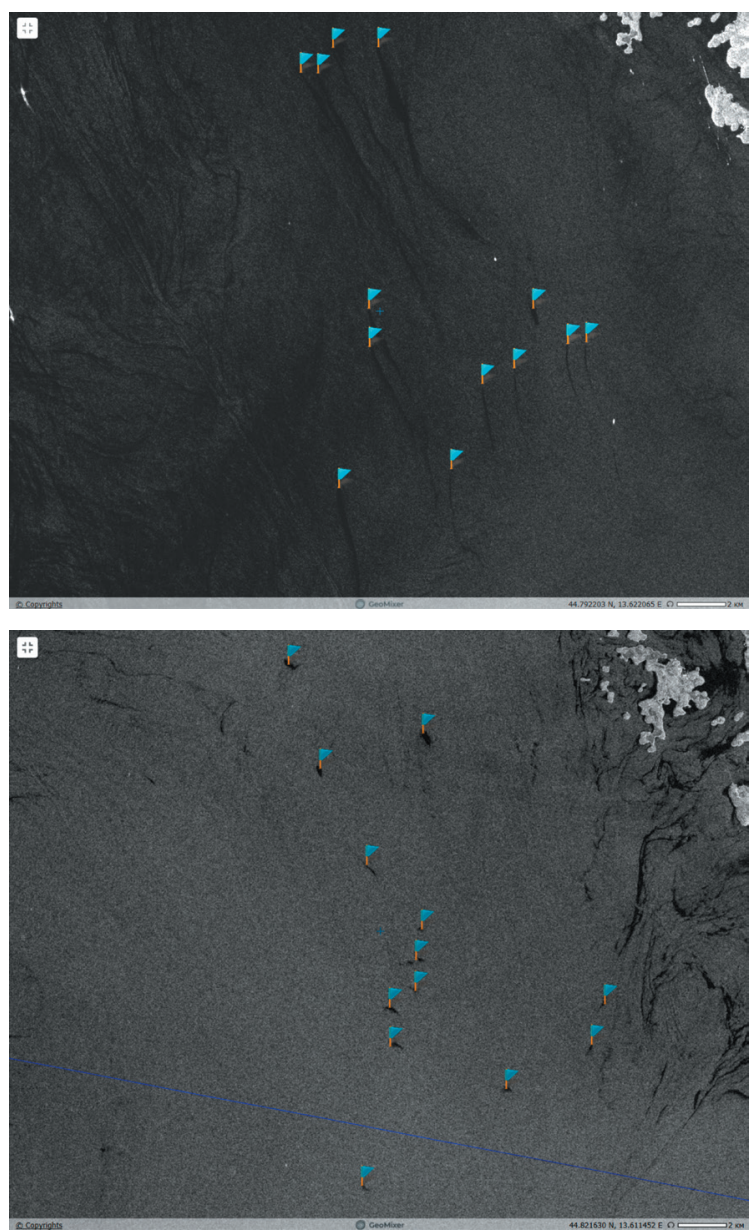

Fig. 5a. Oil slicks detected on the Sentinel-1A/1B SAR images (marked by flags) over the Northern Adriatic off Pula. Images on 11 and 15 September 2018, at 14:57 and 05:18 UTC, respectively. (C) ESA

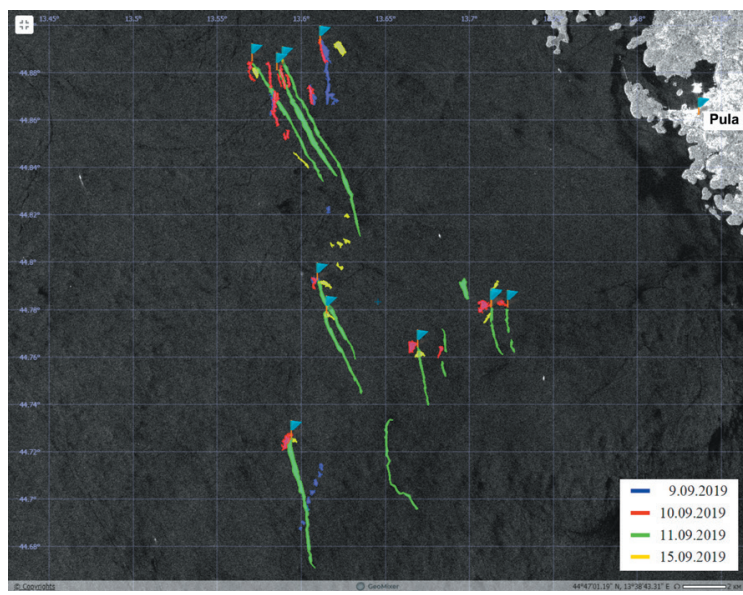

Fig. 5b. Oil slicks (color outlines) detected on the Sentinel1A/1B SAR images acquired on 9-15 September 2018 over the seeps off Pula (spatial slicks grouping mark the origins of oil slicks on the sea surface, shown by flags). Image (C) ESA the slicks have not been spread much from their origins.

It is well-known that an oil slick from a natural seep has the elongated form and drifts away from its origin with sea surface movement. Location of slick origin is more or less constant over a time of 12-24 h, while the shape and length of its slick depend on wind and currents (MACDONALD et al., 2015). Since many slicks of different origin are found in almost the same location on each SAR image, the GIS approach was used to determine their origins and with high probability suggested that they were caused by natural bottom seepage. Figure $5 \mathrm{~b}$ shows the map integrating all slicks outlines and origins extracted from SAR images acquired in the period $9^{\text {th }}-15^{\text {th }}$ September 2018. The slick origins are located at a distance of 13 to $20 \mathrm{~km}$ off the town of Pula above the depths 39-42 m. Slick length varied from $0.3-0.5$ to $9 \mathrm{~km}$, while maximum area of individual slick was $1.7 \mathrm{~km}^{2}$. The absence of earthquakes in this period, as a possible trigger of such phenomena, indicate eventual different origin of these seeps.

Anyway, detection and identification of natural oil slicks on SAR images is a very complex procedure because of the look-alike's presence. Sometimes it is easy to mistaken oil slicks of different origin, and to consider them as slicks formed by seeps. The examples of look-alikes are given in Figure 6. The large oil slick near Rovinj (Fig 6, left) is caused by permanent discharge of oily sewage from the fish factory, which is working in this place since the 60s last century. This slick begins from the shore location of the factory and spreads up to 10-15 $\mathrm{km}$ away from the coast in different directions depending on local currents and prevailing winds. They are visible in each SAR image taken at the wind speed ranging from 2-3 to 10 $\mathrm{m} / \mathrm{s}$. Slicks very similar to seep ones can also appear on SAR images as well. A good example of look-alikes also detected on the SAR image is presented in Figure 6 (right), where numerous groups of oil slicks (small dark patches) are produced by fishing boats visible on the figure as bright points. These were trawling vessels which typically uplift mud from the shallow sea bottom 
Table 1. Basic characteristics of seep slicks detected on SAR images in the marine area off Pula

\begin{tabular}{|c|c|c|c|c|c|c|c|}
\hline Date & $\begin{array}{c}\text { Image } \\
\text { acquisition } \\
\text { time, UTC }\end{array}$ & $\begin{array}{l}\text { Number of } \\
\text { seep slick } \\
\text { candidates }\end{array}$ & $\begin{array}{c}\text { Max. } \\
\text { length } \\
(\mathrm{km})\end{array}$ & $\begin{array}{c}\text { Max. area } \\
\left(\mathrm{km}^{2}\right)\end{array}$ & $\begin{array}{c}\text { Wind } \\
\text { acquisition } \\
\text { time (h) }\end{array}$ & $\begin{array}{c}\text { Wind } \\
\text { direction }\end{array}$ & $\begin{array}{l}\text { Wind speed } \\
\qquad(\mathrm{m} / \mathrm{s})\end{array}$ \\
\hline 9.09 .2018 & 05:19 & 6 & 3.2 & 0.12 & $\begin{array}{l}\text { 01:00 } \\
04: 00 \\
07: 00 \\
01: 00\end{array}$ & $\begin{array}{c}\mathrm{NE} \\
\mathrm{E} \\
\mathrm{ENE} \\
\mathrm{E}\end{array}$ & $\begin{array}{l}3 \\
1 \\
1 \\
2\end{array}$ \\
\hline 10.09 .2018 & $05: 10$ & 15 & 1.6 & 0.16 & $\begin{array}{l}\text { 04:00 } \\
\text { 07:00 } \\
\text { 13:00 }\end{array}$ & $\begin{array}{l}\text { ENE } \\
\text { NE } \\
\text { W }\end{array}$ & $\begin{array}{l}1 \\
1 \\
4\end{array}$ \\
\hline 11.09 .2018 & $16: 57$ & 13 & 9.1 & 0.6 & $\begin{array}{l}16: 00 \\
19: 00 \\
01: 00\end{array}$ & $\begin{array}{l}\text { W } \\
\text { NW } \\
\text { NE }\end{array}$ & $\begin{array}{l}4 \\
1 \\
2\end{array}$ \\
\hline 15.09 .2018 & $05: 18$ & 13 & 0.9 & 0.4 & $\begin{array}{l}\text { 04:00 } \\
\text { 07:00 }\end{array}$ & $\begin{array}{c}\text { ENE } \\
\text { E }\end{array}$ & $\begin{array}{l}1 \\
3\end{array}$ \\
\hline
\end{tabular}
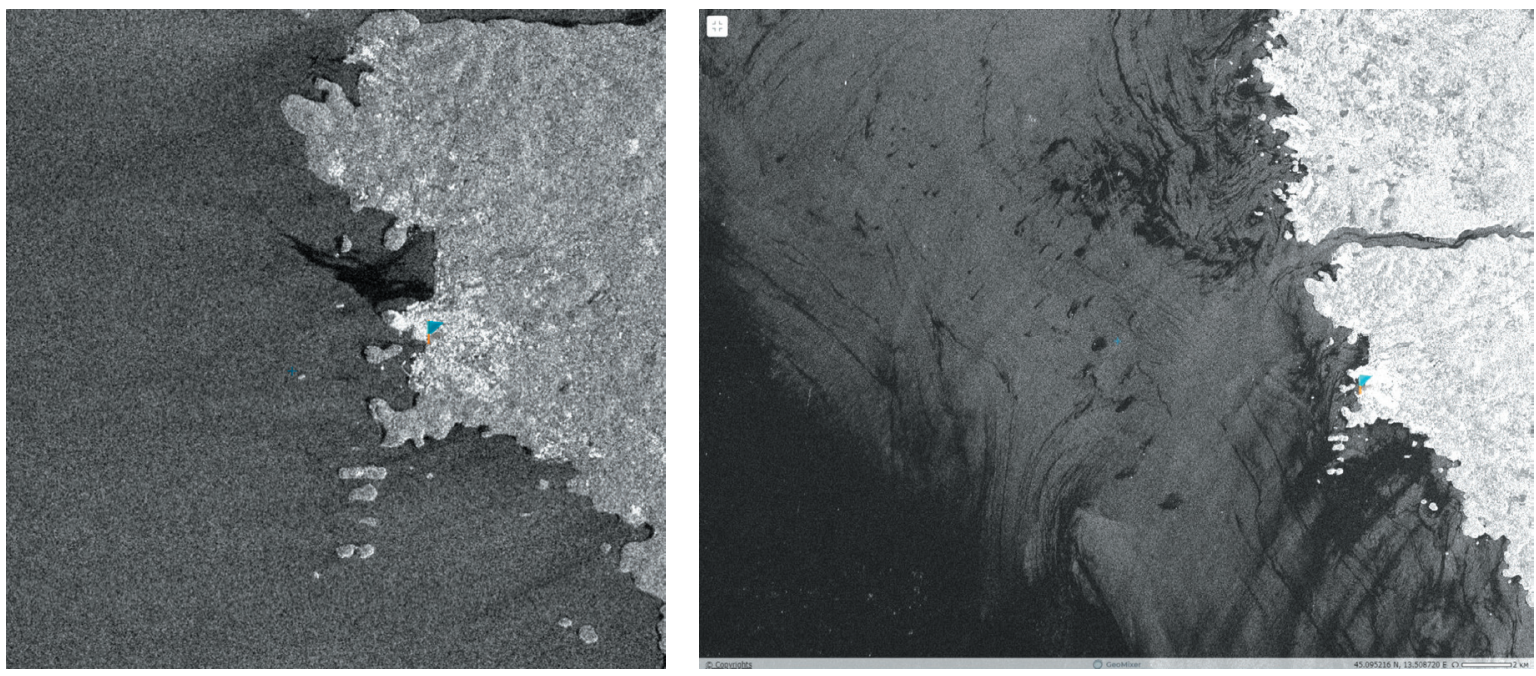

Fig. 6. Look-alikes on the Sentinel-1 SAR images, which have an appearance very similar to seep slicks and can be mistaken for their manifestations. Left: oil spill from the fish factory in Rovinj (2/10/2017, 05:18 UTC, wind NE 4-5 $\mathrm{m} / \mathrm{s})$; right: numerous small slicks produced by fishing boats during the fishing operations (27/08/2017, 05:18 UTC, wind ENE 1-3 m/s). (C) ESA

during trawling operations and give appearance of look-alikes.

\section{CONCLUSIONS}

The SAR imagery acquired over the Adriatic Sea in 2017-2018 documents the presence of natural seepage in two marine ROIs. The distribution of oil slicks detected by satellite remote sensing in these ROIs is studied. Analysis of SAR images have shown that repeated oil slicks visible on SAR images may indicate the presence of underwater sources of oil. Moreover, on some SAR images a group of several vents is clearly seen that may indicate active processes beneath. However, in order to state this unequivocally, additional research is needed.

While the seep in the Italian waters off Civitanova Marche is active and repeating, the seeps in the Croatian waters off Pula have episodic nature and were triggered by some, yet unknown geophysical or bio-geo-chemical process. It seems that oil seep sources are most common and productive in the Central Adriatic (close to the Italian coast from Termoli to Ancona), while 
the Northern Adriatic Sea may produce comparatively little activity of oil seepage. Analysis by DONDA et al., (2019) showed that seep gases in the northern Adriatic Sea are microbial in origin, and are primarily composed of methane, mostly formed within relatively laterally persistent Late Pleistocene peat layers, which are widely distributed throughout and represent the main source of organic matter feeding the seeping gases. Nevertheless, it is in these two areas that we should expect the discovery of new underwater sources of oil by satellites.

The oil-bearing sediments, as clearly indicated by oil production platforms located nearby, are additional evidences of the oil seep activity off the Italian coast, while in the northern Adriatic Sea gas-bearing sediments and gas production platforms occur. This may indicate different types of bottom sediments, seep regimes and even different composition of liquid hydrocarbons entering the sea surface.

The two case studies presented here clearly demonstrate the potential of SAR imagery in detecting oil seep slicks in the Adriatic Sea waters. It is shown that spatial-temporal grouping of oil slicks detected on SAR images at different times allow distinguishing the seep manifestations on the sea surface from patches of a different nature, for example, anthropogenic oil contamination produced by land-based facili- ties and fishing activity. In addition, such slick observations may reveal hidden oil reserves and draw attention to potential oil resources, not previously identified by geophysical methods alone. On the other hand, the contribution of oil seeps should be taken into account when assessing the common oil pollution of the Adriatic Sea.

Finally, it is concluded that the frequent SAR imagery is an excellent mean for monitoring of seepage phenomena, and the results indicate that the use of remote sensing methods can be considered as a good approach to support oil and gas exploration in the Adriatic basin. Once again, the efficiency of the geo-information approach should be mentioned, which, under the conditions of the available SAR data, makes it possible to successfully detect oil seeps.

\section{ACKNOWLEDGEMENTS}

This study was carried out in the frameworks of the state assignment of the Federal Agency for Scientific Organizations (FASO, Russia), theme № 0149-2019-0003. The Sentinel-1A and Sentinel-1B SAR images for this study have been received from European Space Agency via SCANEX Group. Other useful geospatial data have been obtained from Adriatic Atlas project (https://atlas.shape-ipaproject.eu).

\section{REFERENCES}

ARTEGIANNI, A. 1996. The Adriatic Sea hydrography, the European anchovy and its environment (Eds. I. Palomera and P. Rubies). Sciencia Marina (Suppl 2), 60: 33-43.

ARTEGIANNI, A., D. BREGANT, E. PASCHINI, N. PINARDI, F. RAICICH \& A. RUSSO. 1997. The Adriatic Sea general circulation. Part II: Baroclinic circulation structure. J. Phys. Oceanogr., 27: 1515-1532.

BAYRAMOV, E., M. KADA \& M. BUCHROITHNER. 2018. Monitoring oil spill hotspots, contamination probability modeling and assessment of coastal impacts in the Caspian Sea using Sentinel-1, Landsat-8, Radarsat, Envisat and ERS satellite sensors. J. Oper. Oceanogr., 11(1): 27-43.
BRDAREVIĆ, N. \& M. OLUIĆ. 1979. Contribution to the knowledge of tectonic structure of the Adriatic Sea bottom. Proceedings of the Faculty for Mining-Geology-Petroleum Engineering, University of Zagreb, on the Anniversary of the Establishment 1939-1979, $1-14$.

BULJAN, M. 1953. Fluctuation of salinity in the Adriatic. Izvještaj Republičke Ribarstvenobiološke ekspedicije "Hvar" 1948-1949. Acta Adriat., 2: 1-64.

BAOAC. Bonn Agreement Oil Appearance Code. 2016 (https://www.bonnagreement.org/site/ assets/files/1081/special_on_volume_calculation_20160607.docx, accessed March 2019). 
BREKKE, C. \& A.H.S. SOLBERG. 2005. Oil spill detection by satellite remote sensing. Remote Sens. Environ., 95: 1-13.

CASERO, P. \& S. BIGI. 2013. Structural Setting of the Adriatic basin and the main related petroleum exploration plays. Mar. Petrol. Geol., 42: $135-147$.

CONTI, A., A. STEFANON \& G. ZUPPI. 2002. Gas seeps and rock formation in the northern Adriatic Sea. Cont. Shelf Res., 22: 23332344.

COTA, L., T. TROSKOT-ČORBIĆ, G. KOCH \& M. PANDŽıĆ. 2015. "Burano" facijes kao ključni element u istraživanju ugljikovodičnog potencijala srednjeg i južnog Jadrana. Naftaplin: znanstveno-stručno glasilo Hrvatske udruge naftnih inženjera i geologa, 35, 143144: 71-78.

DANDO, P.R., J.A. HUGHES, Y. LEAHY, S.J. NIVEN, L.J. TAYLOR \& C. SMITH. 1995. Gas venting from submarine hydrothermal areas around the island of Milos, Hellenic Arc. Cont. Shelf Res., 15: 913-929.

De MIRANDA, F.P., A.M.Q. MARMOL, E.C. PEDROSO, C.H. BEISL, P. WELGAN \& L.M. MORALES. 2004. Analysis of Radarsat-1 data for offshore monitoring activities in the Cantarell Complex, Gulf of Mexico, using the unsupervised semivariogram textural classifier (USTC). Can. J. Remote Sens., 30(3): 424-436.

DONDA, F., U. TINIVELLA, E. GORDINI, G. PANIERI, V. VOLPI, D. CIVILE, E. FORLIN, L. FACCHIN, M. BURCA, A. COVA \& G.M. FERRANTE. 2019. The origin of gas seeps in the Northern Adriatic Sea. Ital. J. Geosci., 138(2): 171-183.

ETIOPE, G., G. PANIERI, D. FATTORINI, F. REGOLI, P. VANNOLI, F. ITALIANO, M. LOCRITANI \& C. CARMISCIANO. 2014. A thermogenic hydrocarbon seep in shallow Adriatic Sea (Italy): Gas origin, sediment contamination and benthic foraminifera. Mar. Petrol. Geol., 57: 283-293.

EVTUSHENKO, N.V. \& A.Yu. IVANOV. 2013. Oil seep manifestations in the southeastern Black Sea studied using satellite synthetic aperture radar images. Izv. Atm. Ocean. Phys., 49(9): 913-918.

GELETTI, R., A. Del BEN, M. BUSETTI, R. RAMELLA
\& V. VOLPI. 2008. Gas seeps linked to salt structures in the Central Adriatic Sea. Basin Res., 20: 473-487.

GRBEC, B., M. MOROVIĆ, G. BEG PAKLAR, G. KUŠPILIĆ, S. MATIJEVIĆ, F. MATIĆ \& Ž. NINČEVIĆ GLADAN. 2009 The relationship between the atmospheric variability and productivity in the Adriatic Sea area. J. Mar. Biol. Assoc. UK., 89(8): 1549-1558. doi:10.1017/S0025315409000708.

HOVLAND, M. \& P. CURZI. 1989. Gas seepage and assumed mud diapirism in the Italian central Adriatic Sea. Mar. Petrol. Geol., 6(2): 161169.

HOVLAND, M., V.J. GARDNER \& G.A. JUDD. 2002. The significance of pockmarks to understanding fluid processes and geohazards. Geofluids, 2/2: 1-36. (doi.org/10.1046/j.14688123.2002.00028.x).

IVANOV, A. Yu. 2011. Remote sensing of oil films in the context of global changes. In: «Remote Sensing of the Changing Oceans». SpringerVerlag Berlin/Heidelberg. pp. 169-194.

IVANOV, A.Yu. \& V.V. ZATYAGALOVA. 2008. A GIS approach to mapping oil spills in a marine environment. Int. J. Remote Sens., 29(21): 6297-6313.

JATIAULT, R., D. DHONT, L. LONCKE \& D. DUBUCQ. 2017. Monitoring of natural oil seepage in the Lower Congo Basin using SAR observations. Remote Sens. Environ., 191: 258-272.

JUDD, A. \& M. HOVLAND. 2007. Seabed Fluid Flow: The Impact on Geology, Biology and the Marine Environment. Cambridge University Press, UK, 475 p.

KVENVOLDEN, K.A. \& K.C. COOPER. 2003. Natural seepage of crude oil into marine environment. Geo-Mar. Lett., 23: 140-146.

KUZMIĆ, M., I. JANEKOVIĆ, J.W. BOOK, P.J. MARTIN \& J.D. DOYLE. 2007 Modeling the northern Adriatic double-gyre response to intense bora wind: A revisit. J. Geophys. Res., 112 (C3): C03S13, doi:10.1029/2005JC003377.

MACDONALD, I.R., I. LEIFER, R. SASSEN, P. STINE, R. MITCHELL \& N. GUINASSO Jr. 2002. Transfer of hydrocarbons from natural seeps to the water column and atmosphere. Geofluids, 2(2): 95-107. 
MACDONALD, I.R., O.M. GARCIA-PINEDA, A. BEET, S. DANESHGAR ASL, L. FENG, D.P. FRENCH MCCAY, G. GRAETTINGER, J. HOLMES, C. HU, I. LEIFER, F. MUELLER-KARGER, A.R. SOLOW \& G. SWAYZE. 2015. Natural and unnatural oil slicks in the Gulf of Mexico. J. Geophys. Res., 120(12): 8364-8380.

MALVIĆ, T. \& J. VELIĆ. 2008. Geology of fluids settlements. University of Zagreb Faculty of Mining, Geology and Petroleum Engineering, Department of Geology and Geological Engineering: 1-139 (in Croatian).

MATTAVELLI, L., L. NOVELLI \& L. ANELLI. 1991. Occurrence of hydrocarbons in the Adriatic basin. Spec. Publ. EAPG., 1: 369-380.

MOROVIĆ, M., A. IVANOV, M. OLUIĆ, Ž. KOVAČ \& N. TERLEEVA. 2015. Oil spills distribution in the Middle and Southern Adriatic Sea as a result of intensive ship traffic. Acta Adriat., 56(2): 145-156.

MOROVIĆ, M., A. IVANOV \& M. OLUIĆ. 2016. Mapping of oil slicks in the Adriatic Sea: Croatia case study. In: «Oil Pollution in the Mediterranean Sea: Part II - National Case Studies», Hdb Env Chem. Eds. A. Carpenter and A. Kostianoy. Springer International Publishing, pp. 159-178. doi:10.1007/698_2016_38.

NAJOUI, Z., S. RIAZANOFF, B. DEFFONTAINES \& J.-P. XAVIER. 2018. Estimated location of the seafloor sources of marine natural oil seeps from sea surface outbreaks: A new "source path procedure" applied to the northern Gulf of Mexico. Mar. Petrol. Geol., 91: 190-201. doi:10.1016/j.marpetgeo.2017.12.035.
OLUIĆ, M. 2015. Earthquakes-causes and consequences with regards to Croatia and neighboring regions. Prosvjeta, Zagreb, pp. 346.

PERKOVIĆ, M., R. HARSCH \& G. FERRARO. 2016. Oil Spills in the Adriatic Sea. In: «Oil Pollution in the Mediterranean Sea: Part II - National Case Studies», Hdb Env Chem. Eds. A. Carpenter and A. Kostianoy. Springer International Publishing, pp. 97-132.

SPECTRUM GEO. 2017. Oil seep and seismic correlation study for the Adriatic Sea. (https:// www.ee.co.za/article/oil-seep-seismic-correlation-study-adriatic-sea.html).

TUFEKČIĆ, D. 2015. Triassic evaporate facies and their significance on petroleum prospects, mid-Adriatic basin. Proceedings of International Conference and Exhibition June 2015 on oil and gas management, Šibenik, Croatia. 143-144/2015: 79-86.

WILLIAMS, A. \& G. LAWRENCE. 2002. The role of satellite seep detection in exploring the South Atlantic's ultradeep water. Surface exploration case histories: Applications of geochemistry, magnetics, and remote sensing. AAPG Studies in Geology, 48: 327-344.

ZATYAGALOVA, V.V., A.Yu. IVANOV \& B.N. GOLUBOV. 2007. Application of Envisat SAR imagery for the mapping and estimation of natural oil seeps in the South Caspian Sea. In: Proceedings of the Envisat Symposium-2007 (ESA SP-636), Montreux, Switzerland.

ZORE-ARMANDA, M. 1956. On gradient currents in the Adriatic Sea. Acta Adriat., 8: 1-38.

Received: 23 September 2019

Accepted: 21 February 2020 


\title{
Otkrivanje i mapiranje uljnih mrlja pomoću SAR snimaka na Jadranu
}

\author{
Andrei Yu. IVANOVi Mira MOROVIĆ \\ *Kontakt adresa, e-pošta:ivanoff@ocean.ru
}

\section{SAŽETAK}

Ovaj rad daje novu prespektivu problemu istjecanja ugljikovodika iz podmorja na Jadranu, podržavajući pitanja zaštite morskog okoliša kao i eventualno istraživanje nafte i plina. Tehnike daljinskog otkrivanja, osobito snimci "synthetic aperture" radara (SAR) korištene su za otkrivanje uljnih mrlja na površini mora. Na taj su način na sjevernom i na srednjem Jadranu otkrivene dvije grupe mrlja na SAR snimcima dobivenim od europskih satelita Sentinel-1A i Sentinel-1B u razdoblju 2017-2018. Analiza SAR snimaka uz batimetriju, geološke i geofizičke podatke kroz geografski informacijski sustav (GIS) pokazala je da nađene uljne mrlje, vidljive na površini mora, imaju prirodno porijeklo, t.j. da pripadaju fenomenu podmorskih istjecanja, povezanih s postojećim ležištima ugljikovodika. Ove su uljne mrlje koncentrirane na plitkom šelfu i opetovano ili povremeno se pojavljuju u istraživanom području, a u vezi su sa sedimentima koji sadrže naftu ili plin. Nalaženje takvih izvora ili kandidata za izvore, koji su prošli neopaženi od javnosti, ukazuje na učinkovitost ovog pristupa. Konačno, zaključeno je kako su česti SAR snimci odličan alat za monitoring fenomena curenja iz podmorja, a rezultati pokazuju kako se korištenje daljinskih metoda može smatrati dobrim pristupom za istraživanje nafte i plina u jadranskom bazenu.

Ključne riječi: Jadran, SAR snimci, uljne mrlje, curenje ulja iz podmorja, hladna curenja, GIS pristup 